University of Nebraska - Lincoln

DigitalCommons@University of Nebraska - Lincoln

Finance Department Faculty Publications

Finance Department

5-10-2002

\title{
Financial Disclosure and Speculative Bubbles: An International Comparison
}

Benjamas Jirasakuldech

University of Nebraska-Lincoln, b.jirasakuldech@sru.edu

Thomas S. Zorn

University of Nebraska Lincoln, tzorn1@unl.edu

Follow this and additional works at: https://digitalcommons.unl.edu/financefacpub

Part of the Finance and Financial Management Commons

Jirasakuldech, Benjamas and Zorn, Thomas S., "Financial Disclosure and Speculative Bubbles: An International Comparison" (2002). Finance Department Faculty Publications. 9.

https://digitalcommons.unl.edu/financefacpub/9

This Article is brought to you for free and open access by the Finance Department at DigitalCommons@University of Nebraska - Lincoln. It has been accepted for inclusion in Finance Department Faculty Publications by an authorized administrator of DigitalCommons@University of Nebraska - Lincoln. 
Financial Disclosure and Speculative Bubbles: An International Comparison

\author{
Benjamas Jirasakuldech, CFA \\ Department of Finance \\ CBA 210 \\ University of Nebraska-Lincoln \\ Lincoln, NE 68588-0490 \\ Tel: $402-472-2325$ \\ Fax: 402-472-5140 \\ bjirasak@unlserve.unl.edu
}

\author{
Thomas S. Zorn \\ George B. Cook College Professor of Finance \\ and The J.D. Edwards College Professor \\ Department of Finance \\ CBA 210 \\ University of Nebraska-Lincoln \\ Lincoln, NE 68588-0490 \\ Tel: 402-472-6049 \\ Fax: 402-472-5140 \\ tzorn@unlnotes.unl.edu
}

May 10, 2002

We are grateful for comments by participants at a University of Nebraska-Lincoln seminar and at the 2001 FMA conference particularly from Cheol Eun. We also wish to thank Manferd Peterson, Kathy Farrell, and Richard DeFusco. Benjamin Kim provided some of the data and John Geppert provided assistance with programming. 


\title{
Financial Disclosure and Speculative Bubbles: An International Comparison
}

\begin{abstract}
$\underline{\text { Abstract }}$
This paper examines if a country's financial disclosure system affects the likelihood of speculative bubbles. We compare stock returns of eight countries that differ in the quality of their disclosure systems as ranked by Saudagaran and Biddle (1992). We examine the hypothesis that stock prices of firms in countries with a low level of financial disclosure are more prone to speculative bubbles. We employ the duration dependence model developed by McQueen and Thorley (1994) to test for the presence of bubbles. We found that the returns in Japan, a country with a relatively low level of disclosure, shows evidence of a bubble.
\end{abstract}

Key words: Financial Disclosure, Speculative Bubbles, Duration Dependence, and International Comparison. 


\section{Financial Disclosure and Speculative Bubbles: An International Comparison}

\section{Introduction}

The importance of financial reporting, as reflected in accounting standards, has been controversial among academicians. What role, if any, financial disclosure has in determining security prices is not clear? The strong form of the efficient market hypothesis implies that such information is totally redundant. Rational expectations theory predicts that investors always have unbiased forecasts of future values. Excluding the very special case of rational expectations bubbles, speculative bubbles, if they exist, clearly are incompatible with rational expectations. ${ }^{1}$ The existence of speculative bubbles is also controversial. It is nevertheless plausible to suppose that more stringent reporting requirements more closely align market values with fundamentals.

Several studies have claimed that poor accounting and financial reporting practices are the causes of the collapse of the U.S. financial market in October 1929 and the Southeast Asian market in the late 1990s (Zeff (1972) and MacDonald (1998)). Greenspan (1998), Haley (2000), and Vishwanath and Kaufmann (2001) further suggested that accounting practices that help promote transparency make financial crisis less likely. Rathman (1998) proposed the adoption of international accounting standards (IAS) as a means to improve disclosure quality among countries. Support for standardized accounting standards internationally has increased over time. One of the

\footnotetext{
${ }^{1}$ McQueen and Thorley (1994) defined a rational expectations bubble as a situation where stock prices exceed fundamental value. Even though investors know that security prices are not in line with the fundamentals, they do not liquidate their position. They believe that the bubble will continue to grow. The high return during the period the bubble grows is large enough to compensate for the loss when the bubble bursts. This provides the rationale to stay in the market.
} 
supposed benefits of standardizing accounting standards is that this will enhance market efficiency.

This paper examines if the presence of speculative bubbles is related to a country's financial disclosure level. A country's financial disclosure level refers to the quantity and intensity of information reported in meeting statutory requirements, exchange filing and listing requirements, and capital market expectations (Saudagaran and Biddle (1992)). Country disclosure rankings used in this paper are due to Saudagaran and Biddle—-henceforth, S\&B (1992).

The term speculative bubble is used in the general sense that high returns by themselves cause investors to bid prices higher, i.e., speculative bubbles are caused by past price performance rather than underlying fundamentals. Disappointments are inevitable. A speculative bubble, therefore, occurs when upswings are gradual and downswings are rapid; a return pattern that is asymmetric. The duration dependence test is associated with rational expectations bubbles. Duration dependence; however, will be observed whenever investors buy based solely on past price performance and drive prices above their fundamental values.

Research on speculative bubbles began with volatility tests. Shiller (1981) found that U.S. stock prices during the period of 1871-1979 fluctuate too much assuming perfect foresight and a constant discount rate. The excess volatility of stock prices is consistent with stock prices that are characterized by speculative bubbles or meanreverting fads (Shiller (1981) and LeRoy and Porter (1981)). The excess volatility results were controversial (see, for example, Flavin (1983), Kleidon (1986), and Marsh and Merton (1986), and West (1987)). Flavin (1983) and Kleidon (1986) claimed that the 
excess volatility results were due to small sample bias, while Marsh and Merton (1986) attributed them to dividend smoothing by managers. West (1987) developed a specification test that was similar to the Hausman (1978) test and applied it to the Standard \& Poor's 500 index during the 1871-1982 period and the Dow Jones index during the 1928-1978 period. The test allowed for the "no-misspecification" and the "nobubble" hypotheses to be tested separately. He found strong evidence consistent with the existence of bubbles. Lo and MacKinlay (1988) found nonrandom walk behavior in weekly stock market returns from equally-and-value-weighted portfolios using the variance ratio test.

Most of the bubble tests such as the variance bound tests and volatility comparison tests assumed linearity of return patterns. The presence of bubbles, however, implies that the pattern of returns is nonlinear. In 1994, McQueen and Thorley developed a duration dependence test for bubbles. The duration dependence test is different from traditional bubble tests such as the autocorrelation, skewness, and kurtosis tests. The duration dependence test directly addresses the issue of nonlinearility of returns.

Rational expectations bubbles have the characteristic that as the length of the bubble increases the probability of a crash decreases; otherwise the bubble cannot be sustained in a rational market. The duration dependence test allows the probability of the end of a run to differ depending on the run length and on the type of run (positive or negative). Rational expectations bubbles are very specific types of bubble requiring a specific relationship between a departure from fundamental values and the probability of a run ending. The presence of speculative bubbles, a far more general phenomenon, is consistent with duration dependence. Speculative bubbles are likely to exist if it is 
observed that there is a negative relationship between the probability of a run of positive returns ending and the length of the run. In other words, the presence of bubbles suggests positive duration dependence or a negative hazard rate. McQueen and Thorley (1994) found evidence of speculative bubbles in the monthly real returns for both equally-andvalue-weighted portfolios of all NYSE stocks during the period of 1927 to 1991.

In this paper, we examine if financial disclosure has any effect on the likelihood of speculative bubbles. That is, are stock markets in countries with less disclosure more prone to speculative bubbles? We focus on eight major international stock markets. The eight countries are ranked from the highest to the lowest in terms of disclosure. The country's disclosure level rankings (DLR) are from a study done by Saudagaran and Biddle (1992). According to S\&B (1992), the United States has the highest disclosure level, followed in order by Canada, United Kingdom, Netherlands, France, Japan, Germany, and Switzerland. ${ }^{2}$ We employ the nonparametric duration dependence test developed by McQueen and Thorley (1994) to test for the presence of bubbles.

The disclosure of financial information, unfortunately, is only one of many factors that differ among the countries we examine. From this perspective our results cannot be viewed as conclusive. Institutional factors across these countries differ in so many aspects that it is difficult, if not impossible, to control for all of them. In addition, the duration dependence test, unlike regression tests, does not allow for multiple effects.

The empirical results we obtain show that Japan, a country with a relatively low level of disclosure shows evidence consistent with the presence of a bubble, while

\footnotetext{
${ }^{2}$ According to Schienman (1979), Switzerland is known for the reluctance to disclose financial information more than necessary. Companies in Switzerland are required to provide only balance sheet and income statement with minimum disclosure. There is no format of financial statements and it is left to the discretion of managers.
} 
countries in the high disclosure group do not show any evidence of bubbles. However, the no-bubble hypothesis is not rejected for real returns of Germany and Switzerland. Both of which have very low disclosure levels. The implications of our results are discussed in the concluding section.

The rest of the paper is organized as followed: Section II reviews the theory of capital market efficiency and bubbles. Section III presents the duration dependence test procedure. Section II and III follow McQueen and Thorley (1994) closely. Section IV describes the data used and presents the empirical results of the test. Section V presents the conclusions of the study.

\section{Rational Bubble Model}

If capital market is efficient the fundamental value of stock price $\left(P_{t}^{*}\right)$ equals the expected discounted present value of the future cash flows i.e. dividends. ${ }^{3}$

(1) $P_{t}^{*} \equiv \sum_{i=1}^{\alpha} \frac{E_{t}\left[D_{t+i}\right]}{\prod_{j=1}^{i}\left(1+r_{t+j}\right)}$.

However, according to Shiller (1978), Blanchard and Watson (1982), and West (1987), equation (1) is not the only equilibrium solution. Stock prices can be expressed in the following form and still be the solution to the equilibrium condition.

$$
P_{t}=P_{t}^{*}+B_{t}
$$

\footnotetext{
${ }^{3}$ Market efficiency implies that the expected rate of return on a stock is equal the required rate of return, $\mathrm{E}\left[\mathrm{R}_{\mathrm{t}+1}\right]=\mathrm{r}_{\mathrm{t}+1}$ where $\mathrm{E}_{\mathrm{t}}$ denotes the mathematical expectation conditional on the information set at time $t$ and $r_{\mathrm{t}}$ is the required rate of return, $R_{t+1} \equiv\left(P_{t+1}-P_{t}+D_{t+1}\right) / P_{t} . P_{\mathrm{t}}$ represents the stock price at time $t$ and $D_{\mathrm{t}+1}$ represents the future value of dividend at time $t+1$. Assuming the $\mathrm{r}_{\mathrm{t}+\mathrm{i}}=\mathrm{r} \forall \mathrm{i}$, current stock price equals the expected future price and dividends discounted at the investor's required rate of return, $P_{t}=E_{t}\left[P_{t+1}+D_{t+1}\right] /\left(1+r_{t+1}\right)$. The fundamental value of the assets, $P_{t}^{*}$ is obtained by substituting $\mathrm{P}_{\mathrm{t}+1}$ into current stock price equation and solving recursively.
} 
where $\mathrm{E}_{\mathrm{t}}\left[B_{\mathrm{t}+1}\right]=\left(1+r_{\mathrm{t}+1}\right) B_{\mathrm{t}}$ and $\mathrm{r}_{\mathrm{t}+1}$ is assumed to be non-stochastic. Equation (2) indicates that stock prices, in equilibrium might not rationally reflect fundamental value. Stock prices can deviate from their fundamental value because of the bubble $\left(B_{\mathfrak{t}}\right)$ component. The bubble component can be zero but not negative because the security price must be non-negative. A peculiarity of rational expectations bubble is that the bubble component must have always been present.

Security prices can deviate from their fundamental value, in a rational market, by a bubble component $\left(B_{\mathrm{t}}\right)$ that grows at the constant rate of return (r). The probability that a bubble grows must be greater than its corresponding probability of a crash to allow for large positive abnormal returns to compensate for the large negative returns when the market crashes. When security prices contain rational bubbles, unexpected changes in price result from unexpected changes in the fundamental value.

$$
\mu_{t+1}=P_{t+1}^{*}+D_{t+1}-\left(1+r_{t+1}\right) P_{t}^{*}
$$

and unexpected changes in the bubble components,

$$
\eta_{t+1}=B_{t+1}-\left(1+r_{t+1}\right) B_{t}
$$

In other words, the observable unexpected price change is the sum of changes in the fundamental $\left(\mu_{t+1}\right)$ and bubble components $\left(\eta_{t+1}\right)$,

$$
\varepsilon_{t+1}=\mu_{t+1}+\eta_{t+1}
$$

The capital market efficiency hypothesis implies that the expected value of the change in prices $\left(\varepsilon_{t+1}\right)$ is zero. However, even if the market is efficient, the probability of obtaining positive abnormal return can still be greater than one-half. This is due to the skewness of the bubble innovations. As the bubble grows, its innovation is positive but small compared to a one time but large negative innovation when the bubble bursts. Such 
inherent skewness of bubble innovations results in positive excess returns while the bubble continues. The persistence of positive excess return induces positive autocorrelation and longer runs of positive excess returns than expected in the simple model.

The traditional method for detecting speculative bubbles is to count the number of positive and negative returns. If the bubbles are present, the probability of obtaining an abnormal number of positive returns is high. McQueen and Thorley (1994) devised a new test for rational speculative bubbles. Bubbles are characterized as a continuing increase in price or a long run of positive abnormal returns followed by a crash. One of the characteristics of bubbles is a nonlinear pattern in returns. If security prices contain a bubble, there will exist a run of positive abnormal returns that will exhibit duration dependence (a decreasing hazard rate). In other words, the probability of observing the end of a positive run decreases with the length of the run, otherwise a bubble will quickly burst.

Tests of duration dependence can be implemented by examining the hazard rate $\left(h_{\mathrm{i}}\right)$ for runs of positive and negative abnormal returns. McQueen and Thorley (1994) defined the hazard rate as the probability of an observed negative innovation given a sequence of $i$ prior positive innovations, $h_{i}=\operatorname{Prob}\left(\varepsilon_{\mathrm{t}}<\left.0\right|_{\varepsilon_{\mathrm{t}-1}>0, \varepsilon_{\mathrm{t}-2}>0 \ldots \ldots, \varepsilon_{\mathrm{t}-\mathrm{i}}>0, \varepsilon_{\mathrm{t}-\mathrm{i}-1}}\right.$ $<0$ ) decreases with $i$. Specifically, if bubbles exist, the hazard rates for runs of positive excess return, $h_{i+1}<h_{\mathrm{i}}$ for all $i{ }^{4}$ This condition, however, does not hold for runs of negative abnormal returns because rational expectations bubbles cannot be negative. ${ }^{5}$

\footnotetext{
${ }^{4}$ See original paper of McQueen and Thorley (1994) for full detail derivation of this equation.

${ }^{5}$ In some certain situations, positive bubbles are also ruled out. For example, bubbles cannot exist if the market participants have infinite horizons (Tirole (1982)) and if assets have terminal values (Brock (1982)). Tirole (1985) also argued that bubbles cannot occur if the interest rate is greater than the growth rate of
} 
Therefore, duration dependence (a decreasing hazard rate) in a positive run, but not in negative runs, is consistent with the existence of rational bubbles. ${ }^{6}$ Unlike the traditional bubble tests such as autocorrelation, skewness, and kurtosis, duration dependence test allows for a nonlinear pattern of returns.

Speculative bubbles are a far more general and a far more likely phenomenon than rational expectations bubbles. Speculative bubbles are characterized by what some have referred to as irrational exuberance (Shiller, 2000, p.3). If a significant number of investors trade on noise, random positive innovations in price may be perceived as indicating even higher returns in the future. If price increases induce even greater price innovations, then herding behavior can lead to positive duration dependence.

The existence of speculative bubbles is, of course, controversial. Ultimately, it is an empirical issue. There is enough evidence to suggest that it is not unreasonable to consider whether or not the disclosure system affects the likelihood of bubbles emerging in a market.

\section{Duration Dependence Test Procedure}

In this paper, the duration dependence test is performed on the transformed real returns in both dollar-denominated and local currencies. The major reason for using dollar-denominated currency is the growing interest in the international equity markets. Investors possibly view stocks in an international framework and the dollar is the international currency.

economy. Assets that are subject to price bubbles must have a resale value, and a fixed supply (Merton (1987)).

${ }^{6}$ McQueen and Thorley (1994) show that inequality condition $\mathrm{h}_{\mathrm{i}+1}<\mathrm{h}_{\mathrm{i}}$ also holds even when fundamental innovations are not symmetrically distributed. 
We first transform the monthly real returns series of each country into run lengths of positive and negative returns. A run is a sequence of returns that has the same sign. For example, for a data set that consists of ten observations, the maximum numbers of runs can be ten, while the minimum numbers of runs can be one. Hence, the data series consist of a set, $\mathrm{S}_{\mathrm{T}}$ where $\mathrm{T}$ is the number of observations on the random run length, $i$. For each country, the return series being tested are two groups of $\mathrm{T}$ observations of positive and negative runs where the number of observations in each group does not necessary have to be equal. The hazard function $\left(h_{\mathrm{i}}\right)$, is defined as $h_{\mathrm{i}} \equiv \operatorname{Prob}(I=i \mid I \geq i)^{7}$ represents the probability that a specific run ends at length $i$, provided that it lasts until length $i$. McQueen and Thorley (1994) defined the log likelihood function of hazard function as follows:

$$
\mathrm{L}\left(\theta \mid \mathrm{S}_{\mathrm{T}}\right)=\sum_{i=1}^{\alpha} N_{i} \operatorname{Ln} h_{i}+M_{i} \operatorname{Ln}\left(1-h_{i}\right)+Q_{i} \operatorname{Ln}\left(1-h_{i}\right)
$$

The functional form for the hazard function is based on the logistic transformation of the $\log$ of $i$.

$$
h_{i}=\frac{1}{1+e^{-(\alpha+\beta L n i)}},
$$

where $N_{i}$ is the number of completed runs of length $i$ in the sample. $M_{i}$ and $Q_{i}$ are the numbers of completed and partial runs with length greater than $i .{ }^{8}$ Partial runs are the runs that occur at the beginning or at the end of the period investigated. For illustrative purposes, the number of runs of each length for a return series that starts with three

\footnotetext{
${ }^{7}$ The hazard function, rather than density function is used because the former describes the data in terms of conditional probabilities while the latter emphasizes on unconditional probabilities. The hazard function is more relevant to this research because we examine the probability of a run continues conditioned on the length of the run. However, the hazard function is also related to the density function. Hazard rate can be defined as $h_{i}=f_{i} /\left(1-F_{i}\right)$ where $f_{i}$ is the discrete density function and $F_{i}$ is the cumulative density function for $i$.

${ }^{8}$ According to McQueen and Thorley (1994), $\mathrm{Q}_{\mathrm{i}}$ can be ignored when the sample size is large.
} 
positive returns followed by two negative returns, three positive, and one negative will be 1 negative run of length two and 1 positive run of length three. The sample estimated hazard rate for length $i$ is defined as follows:

$$
\hat{h}_{i}=\frac{N_{i}}{\left(M_{i}+N_{i}\right)} .
$$

The null hypothesis of no bubble implies that the probability of a run ending is unrelated to the prior returns, or the probability of obtaining positive and negative abnormal returns is random regardless of the prior sequence. In other words, the null hypothesis of no duration dependence is that $\beta=0$ or a constant hazard rate. The alternative hypothesis of a bubble being present suggests that the probability of a positive run ending should decrease with the length of the run or, specifically, the value of parameter $\beta$, should be negative (decreasing hazard rate).

Duration dependence tests are performed by substituting equation (7) into (6) and maximizing the $\log$ likelihood function with respect to $\alpha$ and $\beta$. The hazard function is estimated as a Logit regression in which the independent variable is the log of the current run length and the dependent variable is 1 if the run ends in the next period and 0 if it does not. Under the null hypothesis of no bubble $(\beta=0)$, the likelihood ratio test (LRT) is asymptotically distributed $\chi^{2}$ with one degree of freedom.

$$
\text { LRT }=2[\log \text { Unrestricted }-\log \text { Restricted }] \sim \chi_{1}^{2} .
$$




\section{Empirical Results}

\subsection{Data}

The data used in this study consist of two parts. The first part is the ranking of country's disclosure levels based on the study done by Saudagaran and Biddle (1992). The second set consists of the end of month stock price indices including dividend income of all eight countries. Both dollar-denominated and local currency price indices are used. The stock price data are the Capital International indices constructed by Morgan Stanley. The data were collected on-line from Morgan Stanley for the period January 1970 to August 2000 for a total of 368 observations.

\subsubsection{Country's Disclosure Ranking}

A ranking of disclosure levels is assigned to the eight countries by using the financial disclosure index created by Saudagaran and Biddle (1992). Table 1 shows the results of country's disclosure level rankings (DLR) based on studies done by S\&B in 1992. ${ }^{9}$ In 1992, S\&B created a new country disclosure index from a survey result of 142 experts who engaged in the process of listing securities in the foreign stock exchanges. The participants (63 U.S. and 79 non-U.S.) were people from different fields of business such as corporate managers, investment bankers, public accountants, stock exchange officers, academics, and so on. The financial disclosure level is designed to include both voluntary and mandatory disclosures. The participants ranked the countries in three areas: statutory reporting requirements, exchange reporting requirements, and capital

\footnotetext{
${ }^{9}$ In 1989, S\&B constructed country disclosure indices by taking the average of the ranking obtained from three previous studies done by Lafferty \& Cairns (1980), Choi \& Bavishi (1982), and Cairns et al (1984). The results suggest that firms in the United States (a disclosure rank of 8) had the highest levels of disclosure, followed in order by the United Kingdom, the Netherlands, Canada, France, Japan, Germany, and Switzerland.
} 
market expectations. S\&B (1992) rankings also provide overall disclosure level scores. The United States is the country that has the most comprehensive disclosure level, followed in order by Canada, the United Kingdom, the Netherlands, France, Japan, Germany, and Switzerland. ${ }^{10}$

Saudagaran and Biddle's—-henceforth S\&B (1992) country disclosure ranking is used in this study for several reasons: First, it is the most comprehensive and widely used country disclosure index (see, for example, Alford, Jones, Leftwich and Zmijewski (1993), Saudagaran and Biddle (1995), and Higgins (1998)). Second, S\&B’s (1992) rankings include both voluntary and mandatory disclosures while other disclosure studies rankings are based solely on mandatory disclosure. Third, the S\&B index is the most recent ranking and is consistent with previous studies (see, for example, Lafferty and Carins (1980), Choi and Bavishi (1982), and Cairns, Lafferty and Mantle (1984)).

Table 2 shows the summary of financial reporting requirements of eight countries prepared by Alford et al. (1993). This summary shows the areas of diversity in accounting standards across countries. The sources of GAAP for all countries except the United States and Canada are derived from government sources only. U.S. GAAP is derived from both public (SEC) and private (FASB) sources, while Canadian GAAP is derived from a private source. According to Ali and Hwang (2000), countries where the private sectors do not get involved in setting accounting standards are associated with less value relevant financial reports. The U.S. disclosure requirements are the most comprehensive in terms of meeting both statutory and investors' demands. There is a relation among the sources of GAAP, level of alignment between financial and tax

\footnotetext{
${ }^{10}$ The results are consistent with the previous studies conducted in 1989 except that the order of countries in the high disclosure group is changed.
} 
accounting, and a country's disclosure level. Countries with low levels of disclosure are associated with a high level of alignment between financial and tax reporting requirements. High conformity between tax and financial reports encourages firms to reduce taxes by reporting lower profits; hence the published financial reports are less valuable for financial analysis (Ali and Hwang (2000)).

Table 2 also shows the diversity in frequency and timing of financial reports. U.S. and Canada require quarterly financial reports, while other countries require semiannual financial reports. Switzerland with the lowest disclosure level does not require any interim financial reports. While the U.S. allows the shortest lag in the interim report (48 days), other countries allow longer interim report lags (4 months). The annual reporting lag ranges from the shortest of 90 days (U.S.) to the longest of eight months (Japan). ${ }^{11}$

\subsubsection{Description of Morgan Stanley Capital International (MSCI) Price Indices}

We examine the eight stock markets for which disclosure rankings are available. They are the United States, Canada, the United Kingdom, the Netherlands, France, Japan, Germany, and Switzerland. The data cover the sample period of January 1970 through August 2000. The price data are value-weighted indices with dividends. They are computed from end-of-month prices of a large sample of firms in each national equity market. The data in both dollar-denominated and local currencies were obtained on-line from Morgan Stanley.

\footnotetext{
${ }^{11}$ The accounting standard in Japan is dual in the sense that the extent of disclosure in annual reports is prescribed by both the Commercial Code (CC) and the Securities and Exchange Law (SEL). The financial reports prepared under the $\mathrm{CC}$, which are distributed to the shareholders, contain less information than those prepared under the SEL, which are reported to the Stock Exchange, but not sent to the shareholders (Cooke (1993)).
} 
Duration dependence tests are implemented on continuously compounded monthly real returns of eight countries for both dollar-denominated and local currencies. To compute the continuously compounded nominal returns, $R_{\mathrm{t}}$, we use the following formula:

$$
R_{\mathrm{t}}=\ln P_{\mathrm{t}}-\ln P_{\mathrm{t}-1},
$$

where $P_{\mathrm{t}}$ represents the price index at the end of the month for period $t$. To create the continuously compounded monthly real returns in dollar-denominated currency, continuously compounded U.S. monthly inflation rates are subtracted from continuously compounded monthly nominal returns. Monthly continuously compounded real returns in local currency are created by subtracting continuously compounded monthly inflation rates of each country from their respective continuously compounded monthly nominal returns. Monthly Consumer Price Index (CPI) data of each country are collected from International Financial Statistics (IFS) Database and Handbook published by the International Monetary Fund. Continuously compounded monthly inflation rates are calculated by taking the first difference of the natural log of the monthly CPI.

There are advantages to using the Morgan Stanley indices. First, the indices cover at least $60 \%$ of the total market capitalization for each country and they are constructed on a uniform basis across countries. ${ }^{12}$ The indices are constructed so as not to include stocks with multiple-listings on foreign stock exchanges. This eliminates the problem of double counting stocks. Second, the MSCI indices do not include the stock of companies that are non-domiciled and that have high cross-ownership. Firms that have high reciprocal ownership provide a continuous flow of information among firms, making access to inside information easier and publicly available information less useful.

${ }^{12}$ Construction of MSCI indices can be obtained from http://www.msci.com 
The avoidance of double counting is important for this study due to the different disclosure levels between countries. According to the U.S. disclosure regulations, stocks of the companies that are non-domiciled but listed on the U.S. stock exchange must follow U.S disclosure rules and regulations. Including the multiple-listed stocks would distort the results of this study.

Figures 1 through 4 show the plots of these indices in dollar-denominated and local currencies. The graph shows that stock markets in all eight countries except Japan were on an upward trend during the past thirty years. The sharp drop for the Japanese indices occurred around March 1990. For the other countries, the value of stock indices plunged in October 1987.

Tables 3 and 4 provide summary statistics of monthly real returns in dollardenominated and local currencies for all eight countries. The means of the stock return series in both currencies are all positive, indicating that stock markets in those countries were trending upward over the thirty-year period. When measured in dollars, the Netherlands (a disclosure rank of 5) has the highest average monthly returns, 0.83 percent, while Canada (a disclosure rank of 7) has the lowest average stock returns of 0.51 percent. France (a disclosure rank of 4 ) has the most volatile market as indicated by the highest standard deviation (6.70\%), while the returns of the United States (a disclosure rank of 8$)$ have the lowest volatility $(4.50 \%)$. The results are the same in dollar and in local currencies except Japan (a disclosure rank of 3) has the lowest mean return denominated in yen.

The dollar-denominated real returns of all countries, except the United Kingdom and Japan, show significant negative skewness coefficients. When local currencies are 
used, all the countries show significant negative skewness, consistent with the presence of bubbles. The significance of the excess kurtosis coefficients in the return series of all the countries in both dollar-denominated and local currencies indicates that the return distribution has "fat tails" when compared to a normal distribution. The fat tail finding implies that price changes occasionally deviate by large amounts. High kurtosis in return series is a possible indication of bubbles. In terms of dollar-denominated returns, Canada shows the highest negative skewness, while the United Kingdom shows the highest kurtosis. The United Kingdom has the highest skewness and excess kurtosis coefficients when returns in pounds are used. The large value of excess kurtosis indicates that the return data are leptokurtic with a sharper peak than the Gaussian distribution. ${ }^{13}$ The evidence of skewness and kurtosis indicates significant third and fourth moments.

During a bubble expansionary period, returns will exhibit positive serial dependence. Tables 3 and 4 also provide the results of the first six sample autocorrelations and the Ljung-Box portmanteau test statistics (Q) for the sixth and twelve-order autocorrelations for real returns in dollar-denominated and local currencies. The first and second order autocorrelations are very small for all the countries. When dollar-denominated returns are used, the Ljung-Box (1978) portmanteau test statistic shows that the null hypothesis of no serial autocorrelation is only rejected for the returns at lag six for the United Kingdom. ${ }^{14}$ Moreover, the Ljung-Box portmanteau test statistic with twelve lags indicates the presence of serial autocorrelation for the dollardenominated returns of Japan. When returns in local currencies are used, the Ljung-Box

\footnotetext{
${ }^{13}$ A Gaussian distribution has a kurtosis of 3.

${ }^{14}$ The chi-square critical values for six degree of freedom at five and ten percent level of significance are 12.59 and 10.64 , respectively. With twelve degrees of freedom, the chi-square value at five and ten percent level of significance are 21.03 and 18.55 , respectively.
} 
portmanteau test statistics with twelve lags rejects the null hypothesis of no serial autocorrelation for returns in the Netherlands and Switzerland at a less than five percent level of significance.

Conventional methods such as tests of skewness, excess kurtosis, and autocorrelation for detecting the serial dependence of the returns assume the stationarity and linearity of returns. The degree of serial dependence among successive price changes could be highly nonstationary during a period characterized by bubbles. Hence, an autocorrelation test that assumes stationarity of returns may have low statistical power in detecting the presence of bubbles. The next section provides the empirical results based on the duration dependence test.

\subsection{Empirical Results}

Tables 5 and 6 report the positive and negative run frequency, sample hazard rate for each run length, Log-Logistic test, and Log Likelihood ratio test for dollardenominated real returns of countries under investigation. Japan (a disclosure rank of 3) shows the longest positive run of 16 months, followed by Germany (a disclosure rank of 2) with a positive run of 14 months. The U.S., France, and Switzerland show the shortest positive run of 9 months.

For real returns in local currencies, Japan also shows the longest positive run of 15 months. This is followed by Canada, the Netherlands, and Germany with a positive run that lasts for 12 months (Table 7). Among the eight countries, France reports the shortest positive run lengths lasting only 8 months.

The negative runs were typically shorter in length, the longest negative run lasts only for 10 and 9 months in both dollar-denominated and local currencies, respectively. 
In terms of dollar-denominated currency, the Netherlands reported the longest negative run, while U.S., U.K., France, and Germany have the longest negative run in the local currency. Japan reports the shortest negative runs length of 6 months is dollardenominated currency; while Switzerland reported the shortest negative run lengths of 6 months in its own currency. It is interesting to note that Japan, a country with a relatively low disclosure level, has the longest positive and the shortest negative runs. This pattern suggests nonrandom behavior of returns that is consistent with the presence of bubbles.

The sample hazard rates as shown in equation (8), are also reported in Tables 5 through 8 . The sample hazard rate determines the probability that a run ends at particular length $i$ (bubble bursts) given that a particular return of the same sign observed in a row that lasts until $i$ (bubble grows). ${ }^{15}$ As shown in Tables 5 and 6, for Japan, there are 93 positive runs and 93 negative runs for a total of 186 runs of real returns (dollardenominated currency). There are 46 runs of positive returns that last at least for one month. 19 out of 46 runs end in the second month. In other words, there is 41.30 percent probability that runs will end in the second month. Out of the remaining 27 runs, 14 runs last for two months, that is, 51.85 percent will end in the third month. Out of the remaining 13 runs, 7 runs last at least three months, 53.85 percent end in the fourth month and of the remaining 6 runs that last at least four months, only 2 or 33.33 percent end in the fifth month and so on. In other words, given a positive run that lasts for three consecutive months, there is a 53.85 percent probability that the return in the next period will be negative, or bubble bursts. The hazard rate of other countries can be interpreted in the same way.

\footnotetext{
${ }^{15}$ Actual run counts do not include the partial runs, which may occur at the beginning or at the end of the period investigated.
} 
In the absence of a speculative bubble, the hazard rate should be constant. For runs of positive dollar-denominated real returns, the hazard rates of all countries are relatively constant for runs of length one to two. There is no particular decreasing or increasing pattern of the hazard rate at horizon beyond two for all the countries except the U.S., U.K., and France. The sample hazard rates of these countries show a consistent decreasing pattern for runs of three to five $(42.31 \%, 20.00 \%$, and $16.67 \%$ for the U.S., $51.72 \%, 28.57 \%$, and $20.00 \%$ for the U.K., and $37.50 \%, 20.00 \%$, and $16.67 \%$ for France, respectively), evidence consistent with the presence of bubbles. The hazard rates of negative runs are relatively constant for all countries. The results are consistent when local currencies are used. All the countries show relatively constant hazard rates at lengths one to three. The hazard rate of France, and Switzerland declines at length four to six $(42.86 \%, 37.50 \%$, and $20.00 \%$ for France, and $50.00 \%, 37.50 \%$, and $20.00 \%$ for Switzerland, respectively). There is not a decreasing or increasing pattern for the hazard rate of negative runs of any country except the U.S. The United States shows a decreasing pattern at length two to four $(57.14 \%, 46.67 \%$, and $37.50 \%)$.

Specifically, the duration dependence test emphasizes on the characteristic of hazard rates. The anti-bubble hypothesis implies a constant hazard rate $(\beta=0)$, a probability of observing a negative or positive abnormal return should be the same. A bubble hypothesis implies a negative slope of the hazard function $(\beta<0)$ for runs of positive not negative abnormal returns. Maximizing the log likelihood function (9) gives the estimates for $\alpha$ and $\beta$.

Table 9 provides the summary of Log-Logistic tests, beta values, the Loglikelihood ratios, and P-values of all the countries in both currencies. For positive runs of 
monthly dollar-denominated real returns, all countries, except the United Kingdom and the Netherlands, show negative betas. However, the magnitude of the coefficients are relatively small except for Japan with the highest beta, -0.384 . For positive runs of monthly real returns in local currency, U.S., U.K., Japan, and Germany yield negative betas. Again, Japan has a slightly smaller beta of -0.297 .

For runs of positive real returns (dollar-denominated currency), the likelihood ratio test in equation (9) of the no-bubble null hypothesis or $\beta=0$ is rejected at a five percent significance level for Japan. When local currencies are used, the null hypothesis of no bubble cannot be rejected for all countries. ${ }^{16}$ For runs of negative real returns, we reject the null hypothesis of a constant hazard rate for the Netherlands (dollardenominated currency) and Switzerland (local currency) at the $10 \%$ level. ${ }^{17}$

The positive duration dependence finding for Japan is consistent with the presence of a bubble. Duration dependence of dollar denominated returns for Japan is not due to the exchange rate. Positive duration dependence was not found in the exchange rate series. Whether or not these findings lend support to the null hypothesis that speculative bubbles are more likely to be present in a country with a low level of disclosure is discussed in the next section.

\section{Conclusions}

This paper used the duration dependence test to examine the hypothesis that a lack of disclosure makes speculative bubbles more likely. This approach is based on the

\footnotetext{
${ }^{16}$ The test was marginally significant for the yen-denominated and pound-denominated real returns.

${ }^{17}$ While there cannot be a negative rational expectations bubble, it is possible to have negative speculative bubbles.
} 
plausible hypothesis that the better informed that investors are, the less likely it is that prices will deviate from fundamental values.

Japan, a country with a low level of disclosure, shows evidence consistent with the existence of a bubble. This, however, is not conclusive evidence in favor of the hypothesis. Switzerland has the lowest level of disclosure but the no-bubble hypothesis is not rejected in that case. For several reasons, Switzerland, however, may not be representative. The Swiss traditionally have a high stake in maintaining both secrecy and conservative business practices. This may make the Swiss unrepresentative. There is, however, no clear pattern for the remaining countries. It is also important to note that the duration dependence test is unlikely to find a bubble unless there is strong evidence to suggest that the no-bubble hypothesis should be rejected.

We would not expect that a low level of disclosure will always produce a bubble. Speculative bubbles are episodic events. We conjecture that the proponents of a relationship between bubbles and disclosure, would at most argue that low disclosure makes bubbles more likely. This research seems to suggest that speculative bubbles and disclosure, particularly in the international context is warranted. 


\section{References}

Alford, A.; Jones J.; Leftwich R.; and M. Zmijewski. "The Relative Informativeness of Accounting Disclosures in Different Countries." Journal of Accounting Research, 31 (1993), 183-223.

Ali, A. and L. S. Hwang. "Country-Specific Factors Related to Financial Reporting and the Value Relevance of Accounting Data." Journal of Accounting Research, 38 (2000), 1-21.

Biddle, G. C. and S. M. Saudagaran. "The Effects of Financial Disclosure Levels on Firms' Choices Among Alternative Foreign Stock Exchanges." Journal of International Financial Management and Accounting, 1 (1989), 55-87.

Blanchard, O. J., and M. W. Watson. "Bubbles, Rational Expectations, and Financial Markets." In Crisis in the Economic and Financial System, P. Wachtel, ed. Lexinton, MA: Lexington Books (1982).

Brock, W. A. "Speculative Hyperinflations in Maximizing Models: Corrigendum and Clarification.” Working Paper, University of Wisconsin, Madison (1982).

Cairns, D.; M. Lafferty and P. Mantle. Survey of Accounts and Accountants 1983-84, London, England: Lafferty Publications, 1984.

Choi, F. D. S. and V. B. Bavishi, "Diversity in Multinational Accounting." Financial Executive, (1982), 45-49.

Cooke, T. E. "Disclosure in Japanese Corporate Annual Reports." Journal of Business Finance and Accounting, 20 (1993), 521-535.

Flavin, M. A. "Excess Volatility in Financial Markets: A Reassessment of the Empirical Evidence.” Journal of Political Economy, 91 (1983), 929-956.

Greenspan, A. "Statement to The U.S. Senate Committee on the Budget." Federal Reserve Bulletin, 84 (1998), 936-938.

Haley, U. C. "Corporate Governance and Restructuring in East Asia: An Overview" Seoul Journal of Economics, 13 (2000), 225-251.

Hausman, J. A. "Specification Tests in Econometrics.” Econometrica, 46 (1978), 12511271.

Higgins, H. N. "Analyst Forecasting Performance in Seven Countries." Financial Analysts Journal, (1998), 58-62. 
Kleidon, A. W. "Variance Bounds Tests and Stock Price Valuation Models." Journal of Political Economy 94, (1986), 953-1001.

Lafferty, M. and D. Cairns, Financial Times Survey of Annual Reports 1980, London, England: Financial Times Business Information, 1980.

LeRoy, S. F. and R. D. Porter. "The Present-Value Relation: Tests Based on Implied Variance Bounds.” Econometrica, 49 (1981), 555-574.

Leuz, C. and R. E. Verrecchia. "The Economic Consequences of Increased Disclosure." Journal of Accounting Research, 38, (2000), 91-124.

Lo, A. W. and A. C. MacKinlay. "Stock Market Prices Do Not Follow Random Walks: Evidence from a Simple Specification Test." Review of Financial Studies, 1 (1988), 897-916.

MacDonald, S. B. "Transparency in Thailand's 1997 Economic Crisis: The Significance of Disclosure." Asian Survey, 38 (1998), 688-703.

Marsh, T. A. and R.C. Merton. "Dividend Variability and Variance Bound Tests for the Rationality of Stock Market Prices." American Economic Review, (1986), $483-498$.

McQueen, G. and S. Thorley. "Bubbles, Stock Returns, and Duration Dependence." Journal of Financial and Quantitative Analysis, 29 (1994), 379-401.

Merton, R.C. "On the Current State of the Stock Market Rationality Hypothesis." In Macroeconomic and Finance: Essays in Honor of Franco Modigliani, R. Cambridge: The MIT Press (1987).

Mueller, G. G.; H. Gernon; and G. Meek. Accounting: An International Perspective. New York: Business One Irwin, 1994.

Pratt, J. and G. Behr. "Environmental Factors, Transaction Costs, and External Reporting: A Cross-National Comparison." The International Journal of Accounting, (1987), 1-24.

Prowse, S. D. "The Structure of Corporate Ownership in Japan." Journal of Finance, 3 (1992), 1121-1140.

Rahman, M. Z. "The Role of Accounting in The East Asian Financial Crisis: Lessons Learned?" Transnational Corporation, 7 (1998), 1-52.

Saudagaran, S. M. and G. C. Biddle. "Financial Disclosure Levels and Foreign Stock Exchange Listing Decisions." Journal of International Financial Management and Accounting, 4 (1992), 106-148. 
Saudagaran, S. M. and G. C.Biddle. "Foreign Listing Location: A Study of MNCs And Stock Exchanges in Eight Countries." Journal of International Business Studies, (1995), 319-341.

Schieneman, G. S. "International Accounting: Issues and Perspective." Journal of Accounting Auditing \& Finance, 3 (1979), 21-30.

Shiller, R. J. "Do Stock Prices Move Too Much to be Justified by Subsequent Changes in Dividends?" American Economic Review, 71 (1981), 421-436.

Shiller, R. J. "Rational Expectations and the Dynamic Structure of Macroeconomic Models: A Critical Review." Journal of Monetary Economics, 5 (1978), 1-44.

Shiller, R. J. Irrational Exuberance. Princeton, New Jersey: Princeton University Press, 2000

Tirole, J. "On the Possibility of Speculation under Rational Expectations." Econometrica, 50 (1982), 1163-1181.

Tirole, J. “Asset Bubbles and Overlapping Generations.” Econometrica, 53 (1985), 14991527.

Vishwanath, T. and D. Kaufmann. "Toward Transparency: New Approaches and Their Application to Financial Markets." World Bank Research Observer, 16 (2001), 41-47.

West, K. D. “A Specification Test for Speculative Bubbles.” Quarterly Journal of Economics, 102 (1987), 553-580.

Zeff, S. A. 1972. Forging Accounting Principles in Five Countries. Champaign, IL: Stipes

Zhang, P. G. "IMF And The Asian Financial Crisis." World Scientific Asian Economic Profiles, London, England (1998). 
Figure 1: Monthly MSCI Nominal Equity Indices Value (US Currency) for Countries With Relatively High Disclosure (January 1970-August 2000)

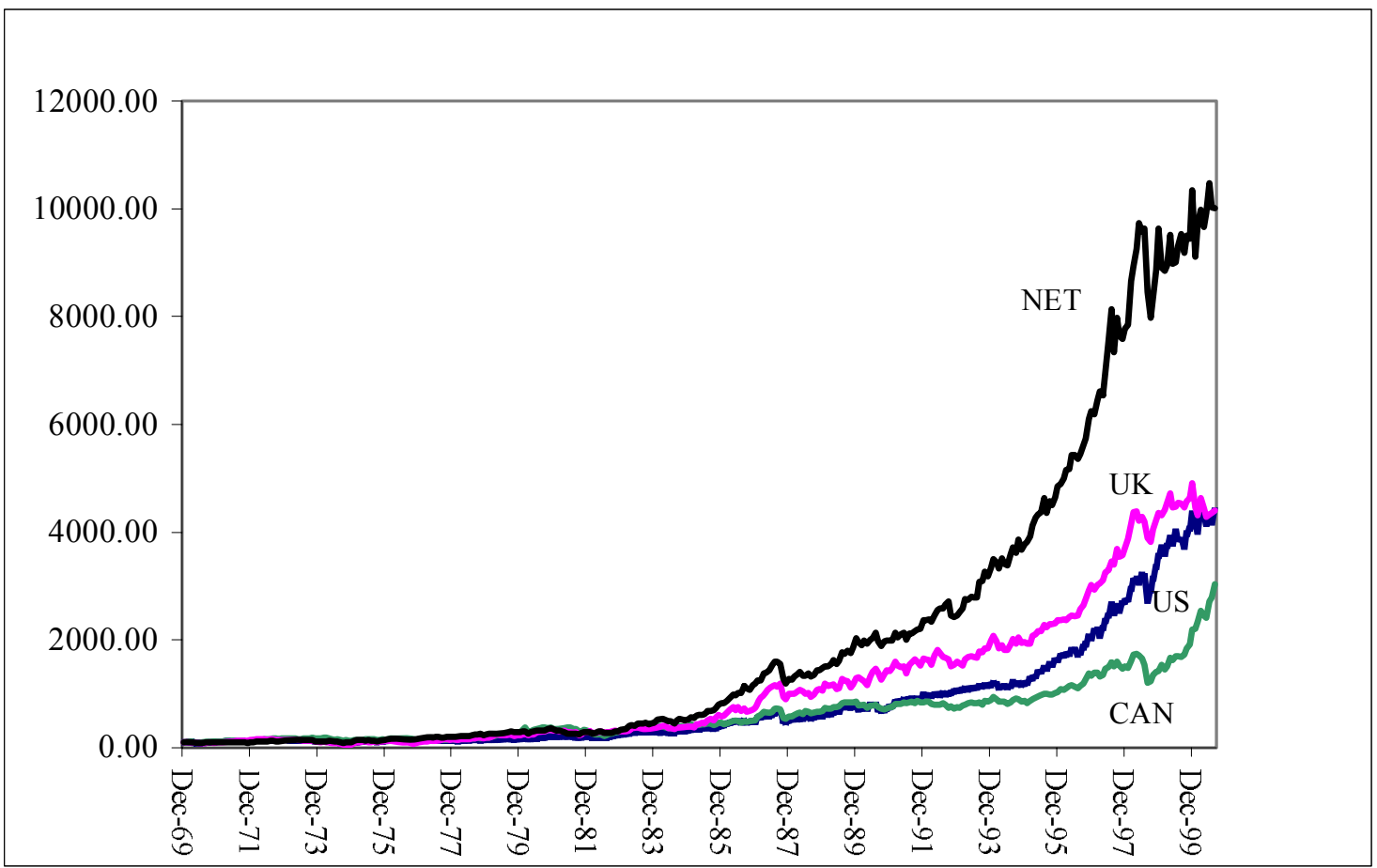

Figure 2: Monthly MSCI Nominal Equity Indices Value (US Currency) for Countries With Relatively Low Disclosure (January 1970-August 2000)

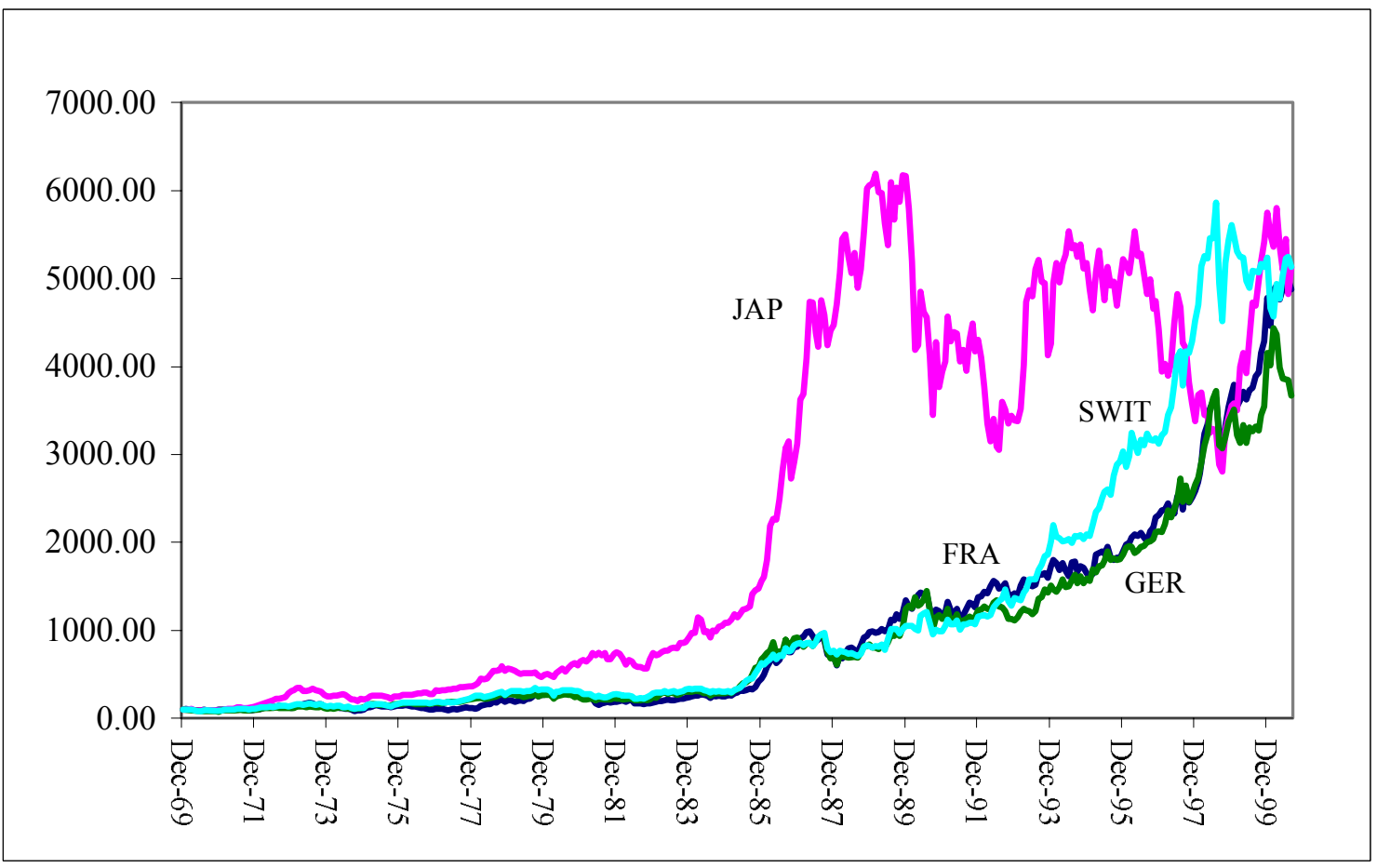


Figure 3: Monthly MSCI Nominal Equity Indices Value (Local Currency) for Countries With Relatively High Disclosure (January 1970-August 2000)

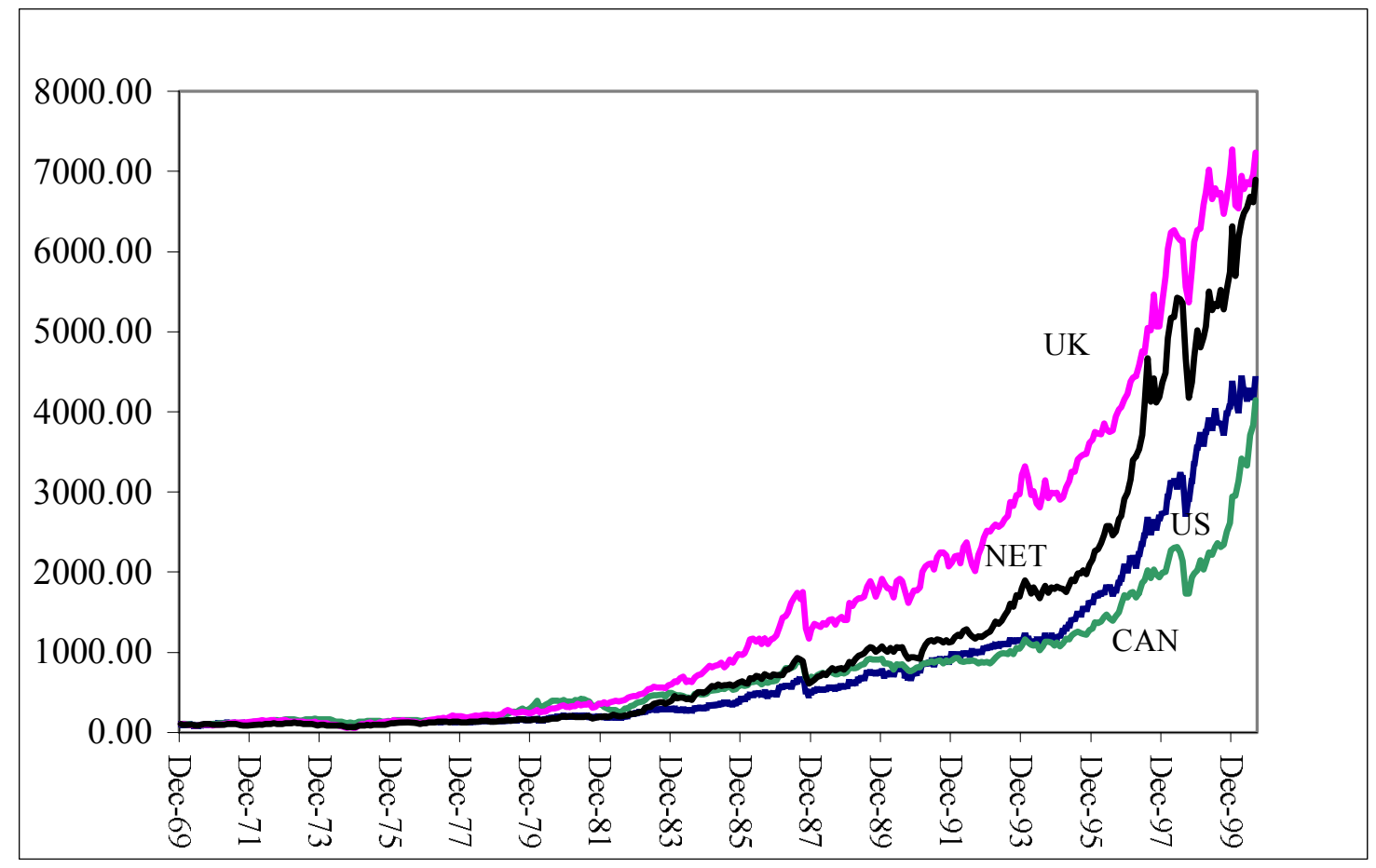

Figure 4: Monthly MSCI Nominal Equity Indices Value (Local Currency) for Countries With Relatively Low Disclosure (January 1970-August 2000)

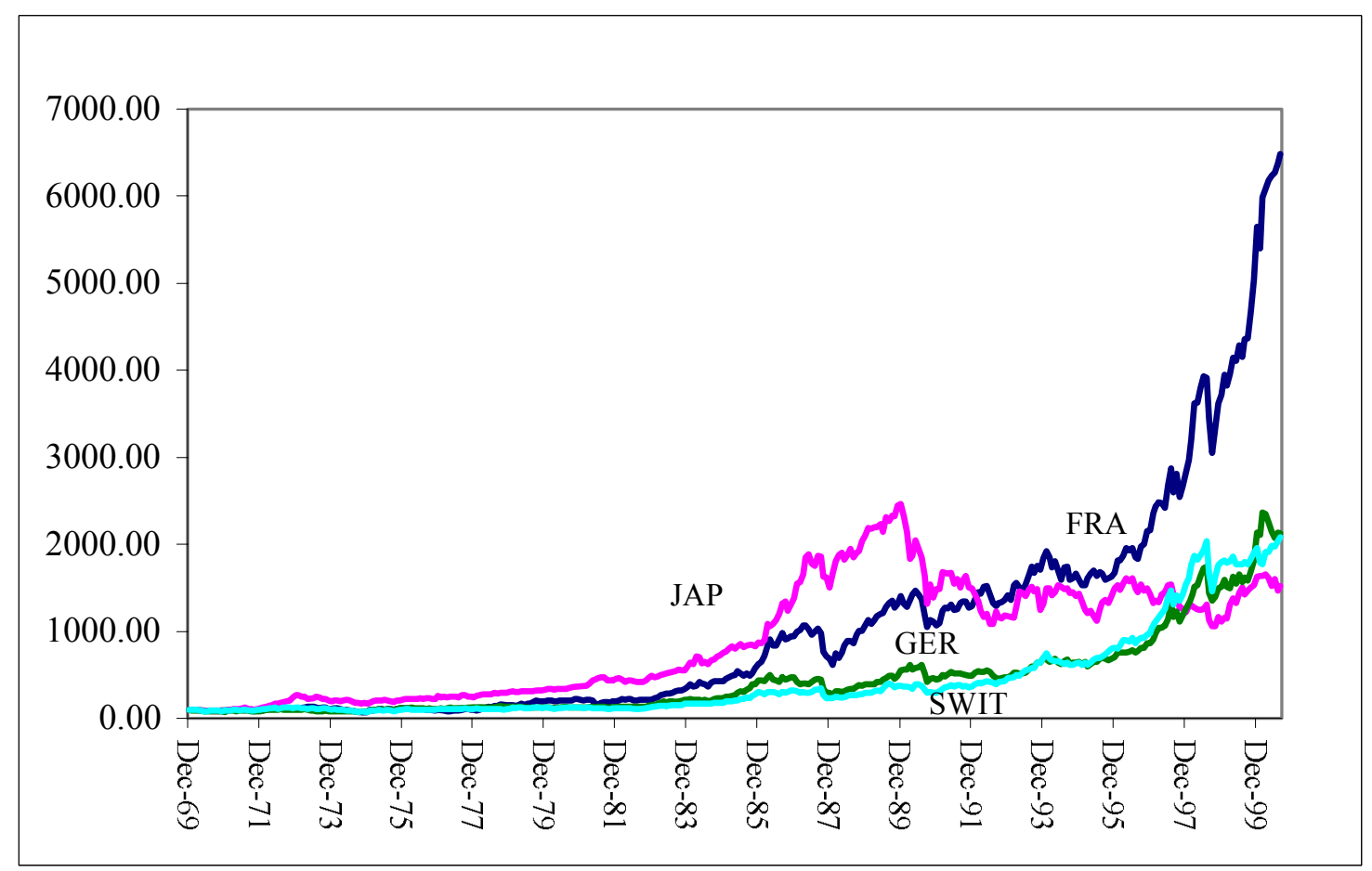


Table 1

Country Disclosure Level Ranks ${ }^{1}$

Saudagaran and Biddle (1992)

\begin{tabular}{lcc}
\hline Country & $\begin{array}{c}\text { Overall }^{2} \\
\text { Disclosure } \\
\text { Levels }\end{array}$ & $\begin{array}{c}\text { Disclosure }^{2} \\
\text { Level } \\
\text { Rank (DLR) }\end{array}$ \\
\hline The United States & 7.28 & 8 \\
Canada & 6.41 & 7 \\
The United Kingdom & 6.02 & 6 \\
The Netherlands & 4.75 & 5 \\
France & 4.17 & 4 \\
Japan & 3.83 & 3 \\
Germany & 3.81 & 2 \\
Switzerland & 2.60 & 1 \\
\hline
\end{tabular}

1. This country's disclosure ranking is obtained from the study done be by Saudagaran and Biddle (1992). The disclosure rank is based on the survey results of 142 experts.

2. Overall disclosure level is based on three areas of disclosure: statutory reporting requirement, exchange reporting requirement, and capital market expectation. See original paper for the score of disclosure in each area.

3. The higher DLR indicates higher disclosure level where '8' ('1') represents the highest (lowest) disclosure level. The DLR provided by this survey is the same as the DLR conducted by Saudagaran and Biddle (1989) except the rank for Canada is changed from 5 to 7. 


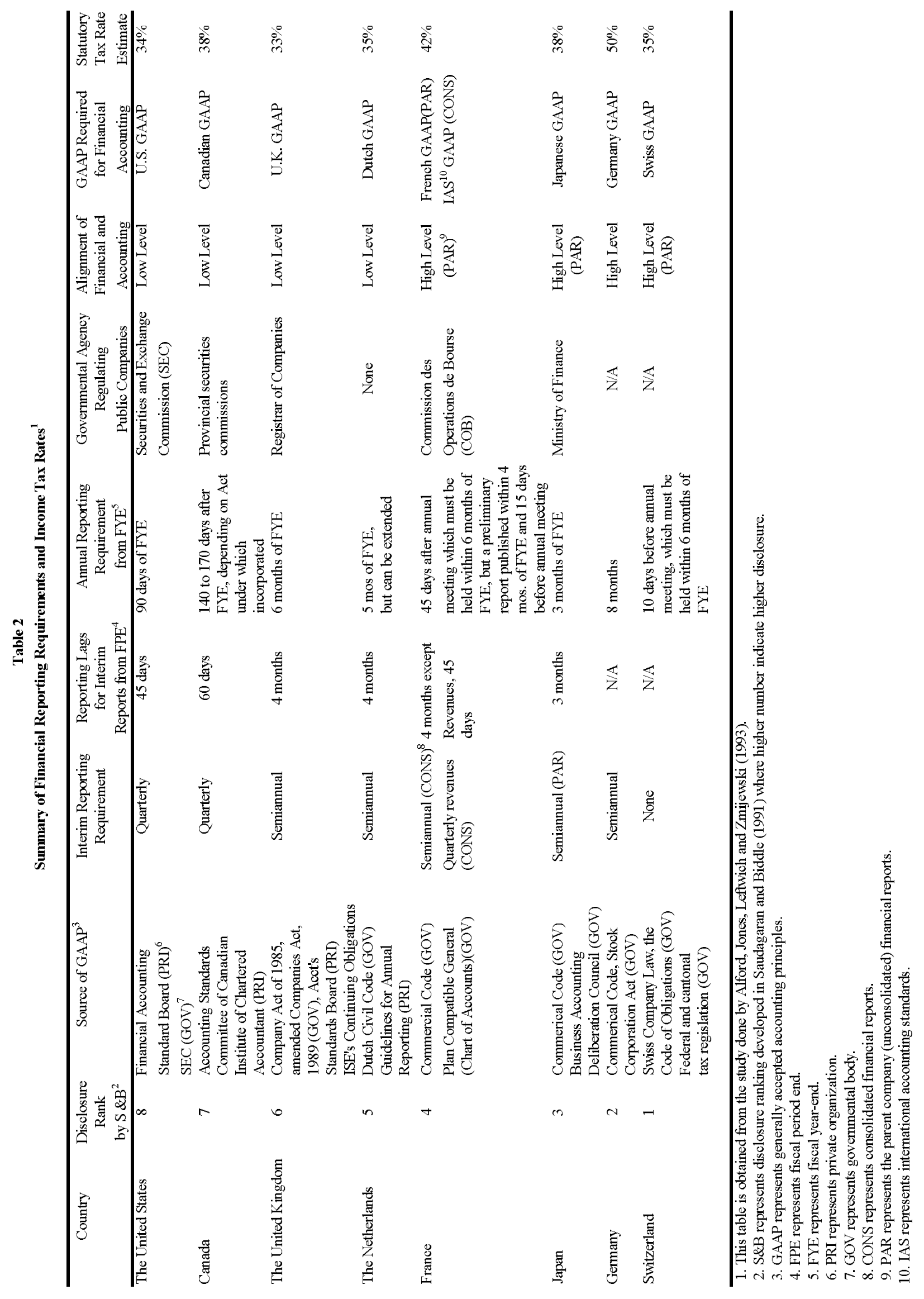




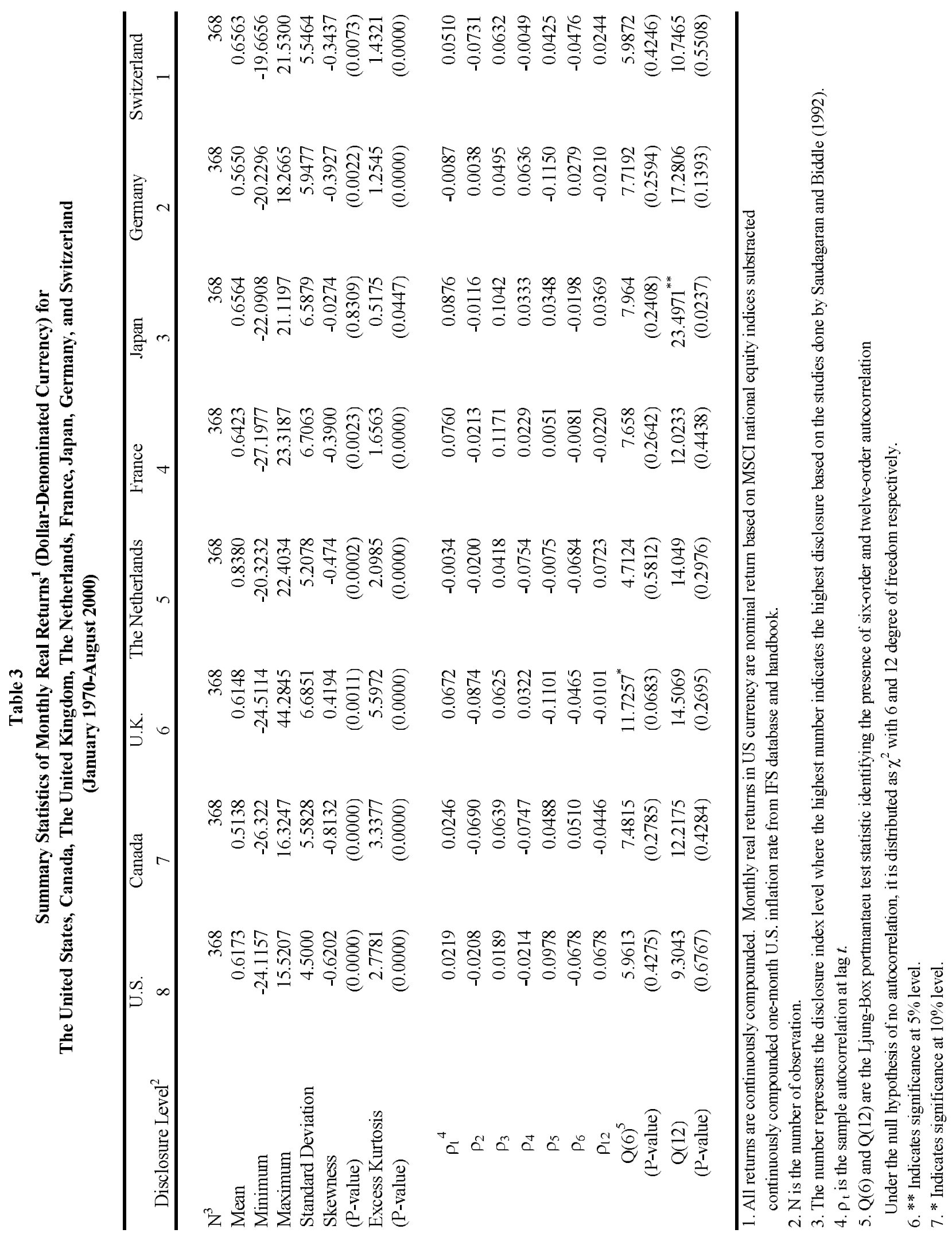




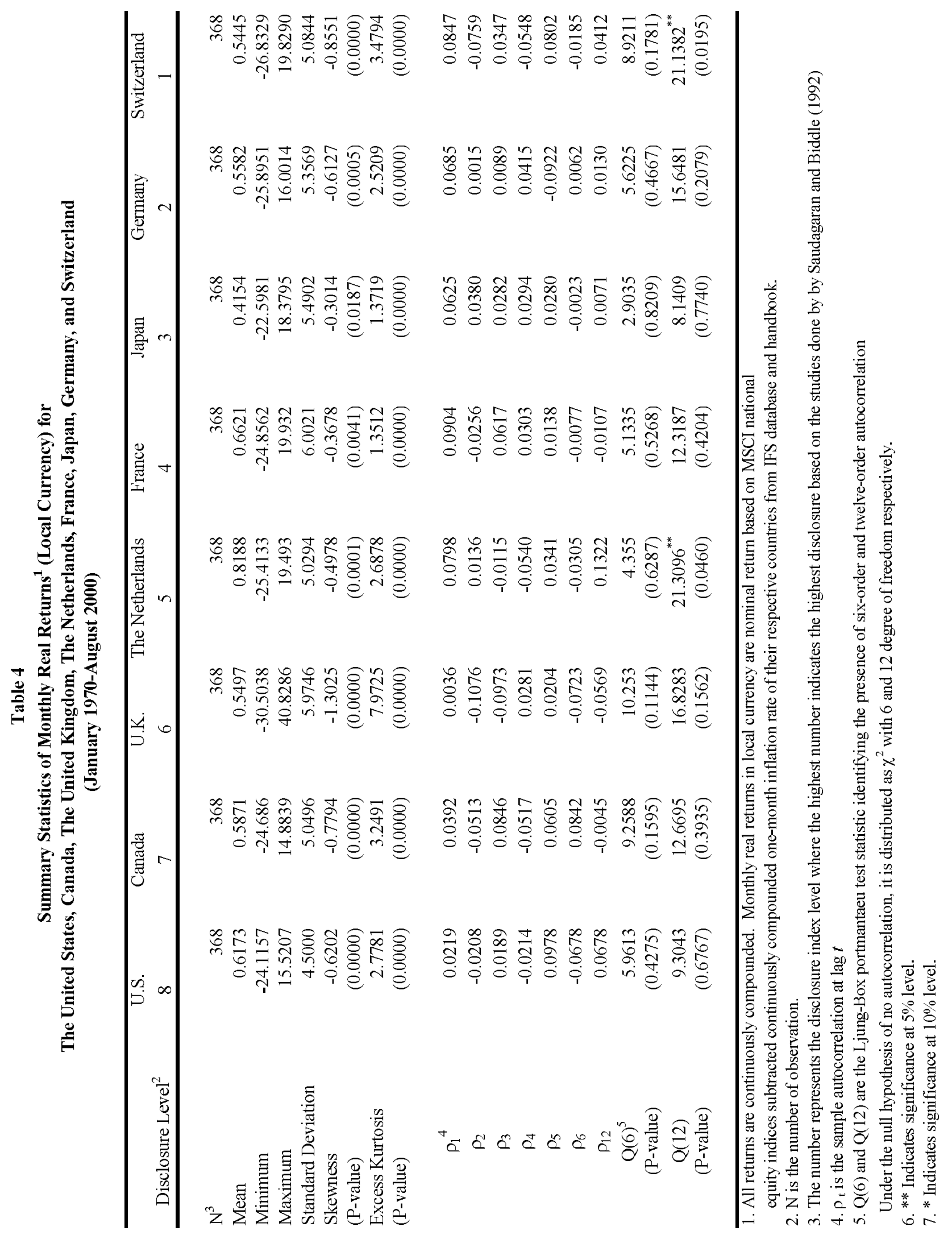




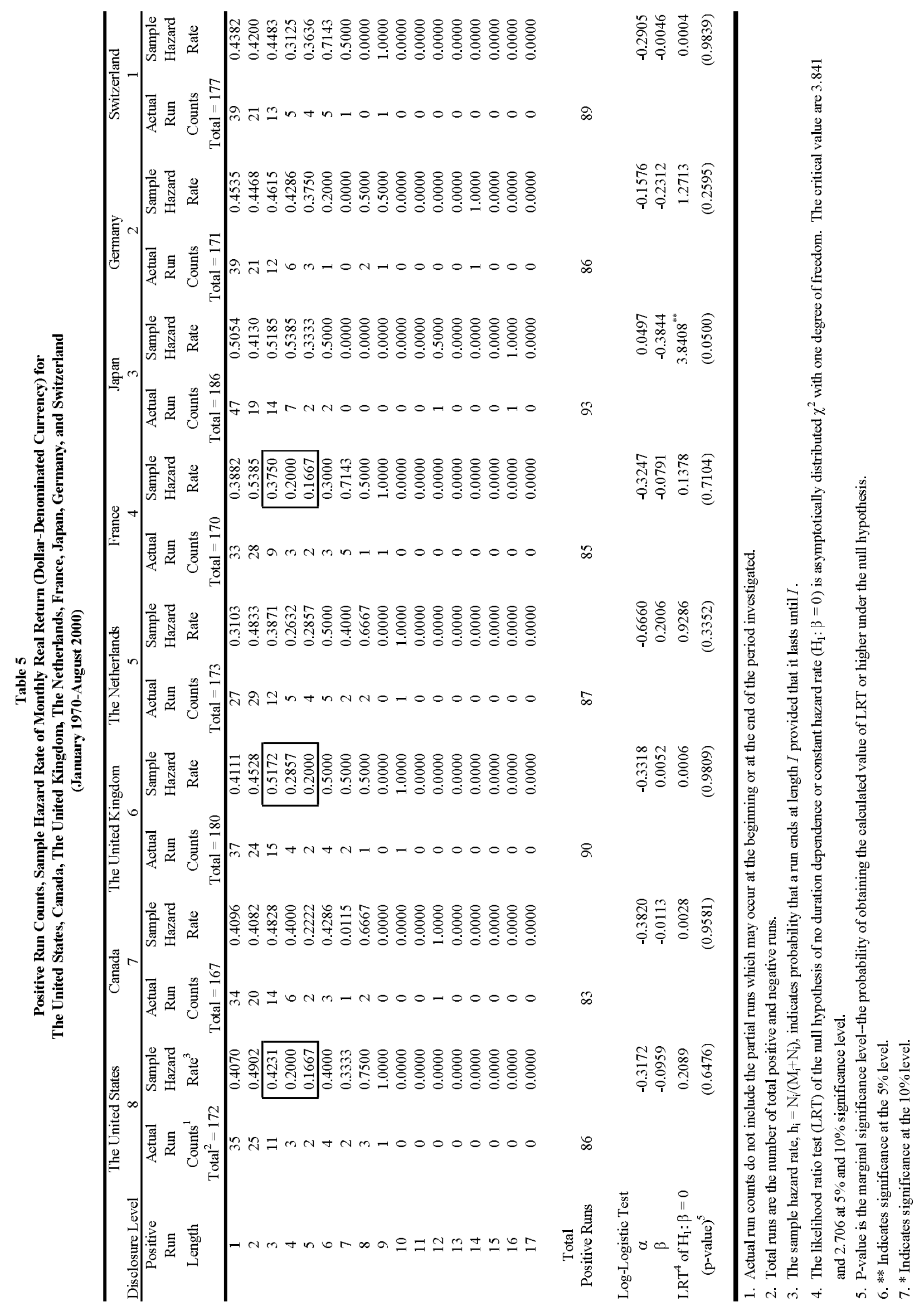




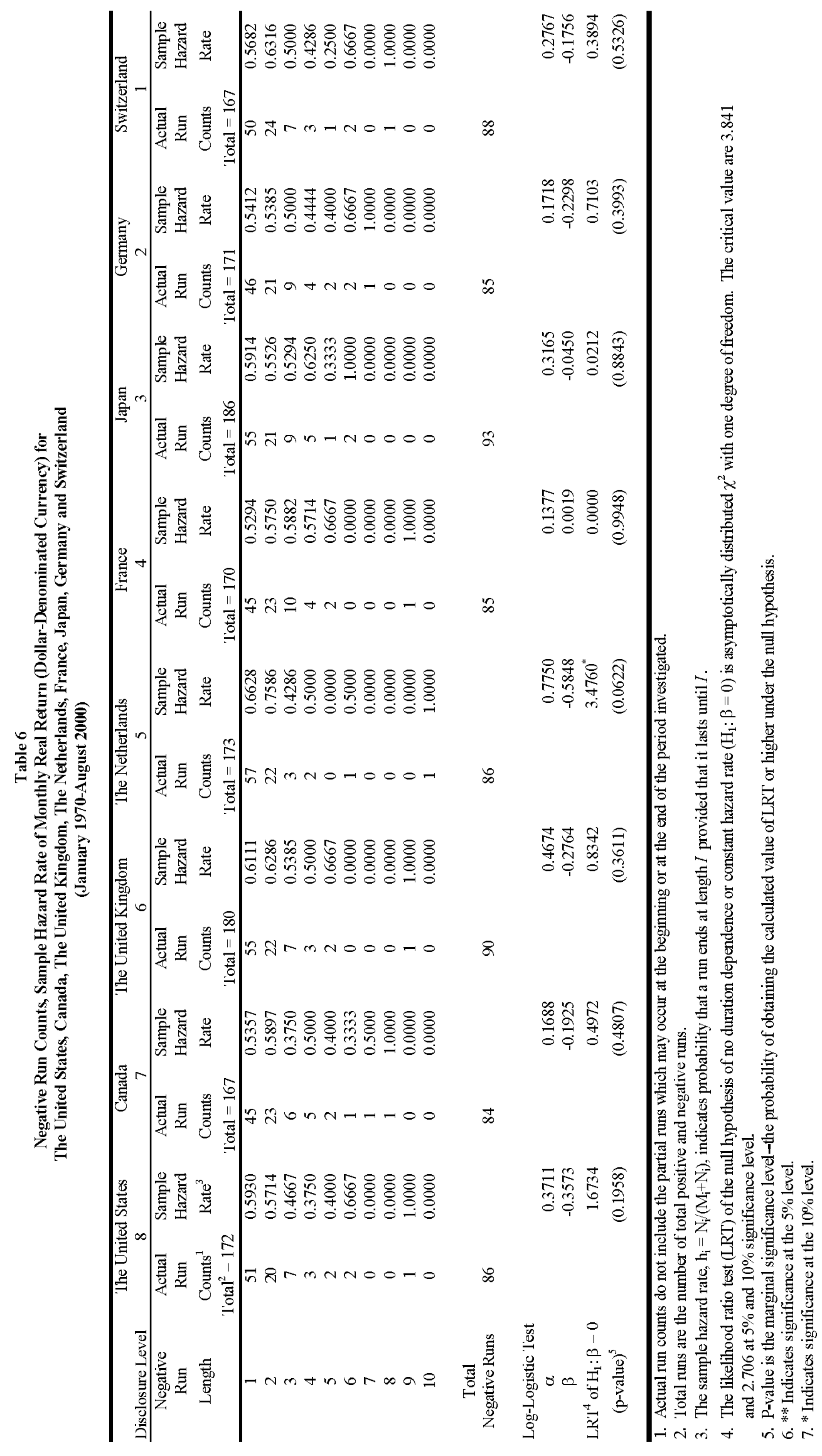




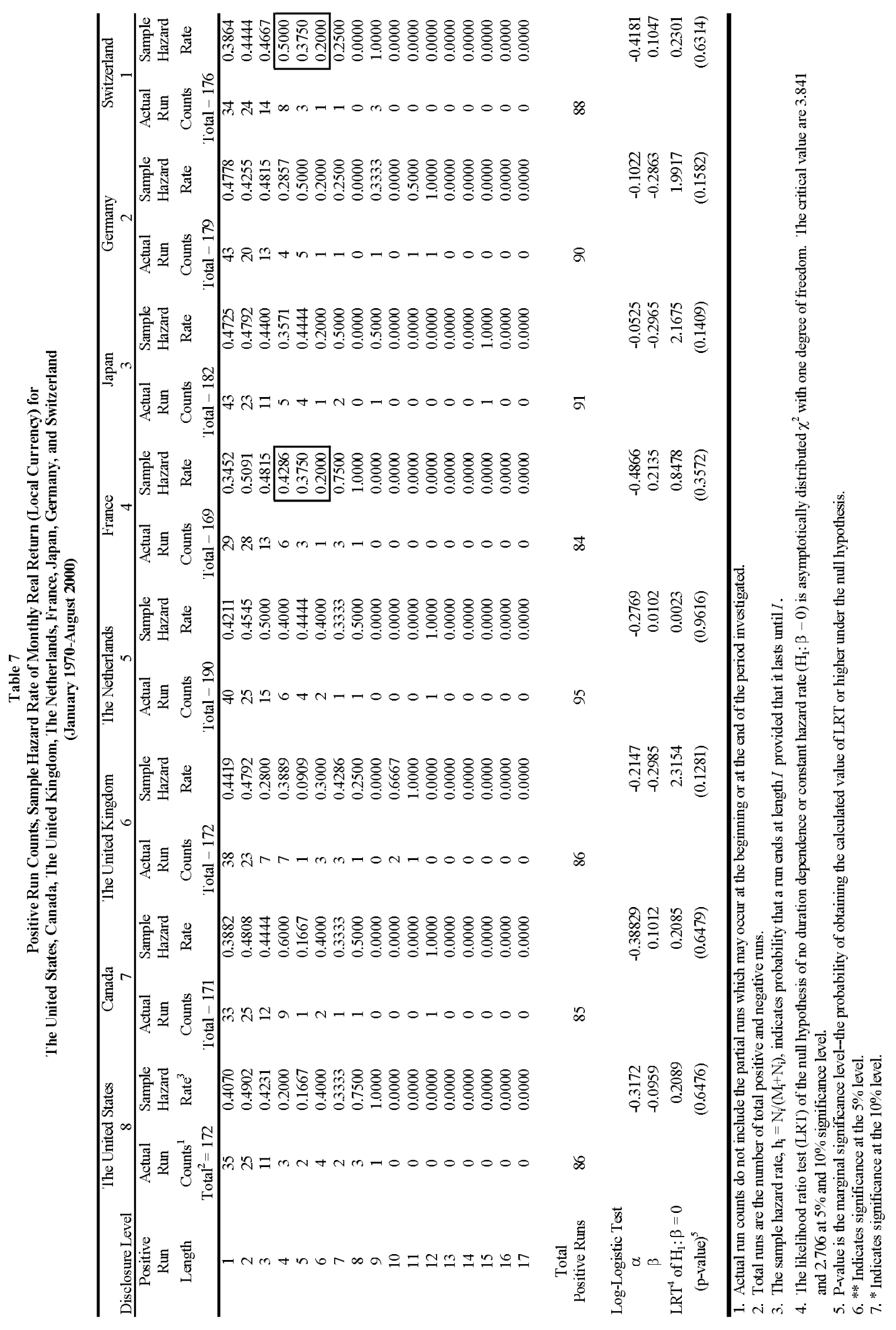




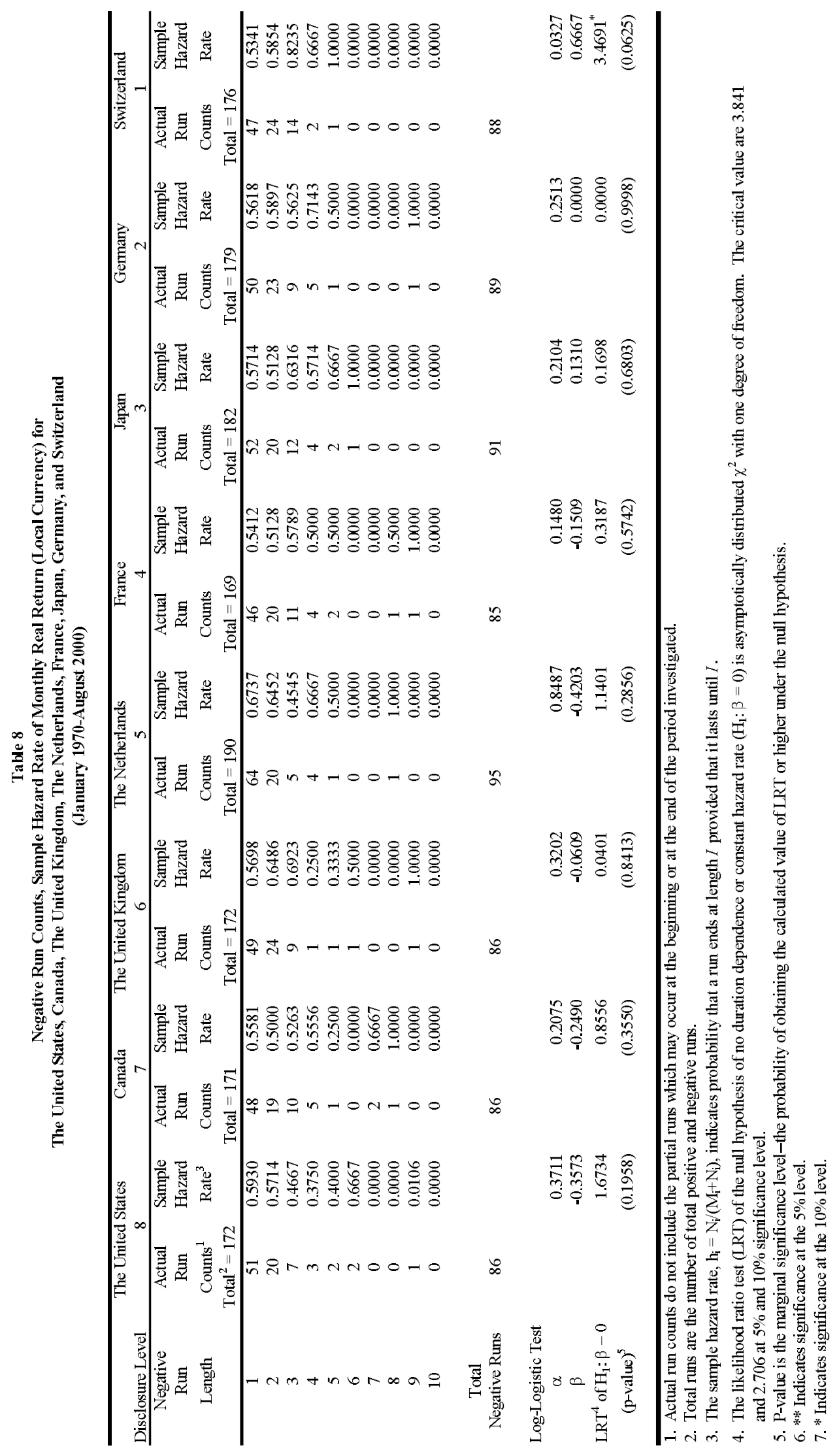


Table 9

Summary of the Log-Logistic Test of Duration Dependence ${ }^{1}$

The United States, Canada, The United Kingdom, France, Japan, Germany, and Switzerland (January 1970-August 2000)

\begin{tabular}{|c|c|c|c|c|c|c|}
\hline \multirow[b]{2}{*}{$\begin{array}{l}\text { Disclosure } \\
\text { Level }^{2}\end{array}$} & \multirow[b]{2}{*}{ Country } & & \multicolumn{2}{|c|}{ US Currency } & \multicolumn{2}{|c|}{ Local Currency } \\
\hline & & & $\begin{array}{l}\text { Positive } \\
\text { Runs }\end{array}$ & $\begin{array}{c}\text { Negative } \\
\text { Runs }\end{array}$ & $\begin{array}{l}\text { Positive } \\
\text { Runs }\end{array}$ & $\begin{array}{c}\text { Negative } \\
\text { Runs }\end{array}$ \\
\hline \multirow[t]{3}{*}{8} & The United States & $\beta$ & -0.096 & -0.357 & -0.096 & -0.357 \\
\hline & & $\mathrm{LRT}^{3}$ & 0.209 & 1.673 & 0.209 & 1.673 \\
\hline & & P-Value & $(0.6476)$ & $(0.1958)$ & $(0.6476)$ & $(0.1958)$ \\
\hline \multirow[t]{3}{*}{7} & Canada & $\beta$ & -0.011 & -0.193 & 0.101 & -0.249 \\
\hline & & LRT & 0.003 & 0.497 & 0.209 & 0.856 \\
\hline & & P-Value & $(0.9581)$ & $(0.4807)$ & $(0.6479)$ & $(0.3550)$ \\
\hline \multirow[t]{3}{*}{6} & The United Kingdom & $\beta$ & 0.005 & -0.276 & -0.299 & -0.061 \\
\hline & & LRT & 0.001 & 0.834 & 2.315 & 0.040 \\
\hline & & P-Value & $(0.9809)$ & $(0.3611)$ & $(0.1281)$ & $(0.8413)$ \\
\hline \multirow[t]{3}{*}{5} & The Netherlands & $\beta$ & 0.201 & -0.585 & 0.010 & -0.420 \\
\hline & & LRT & 0.929 & $3.476^{*}$ & 0.002 & 1.140 \\
\hline & & P-Value & $(0.3352)$ & $(0.0622)$ & $(0.9616)$ & $(0.2856)$ \\
\hline \multirow[t]{3}{*}{4} & France & $\beta$ & -0.079 & 0.002 & 0.214 & -0.151 \\
\hline & & LRT & 0.138 & 0.000 & 0.848 & 0.319 \\
\hline & & P-Value & $(0.7104)$ & $(0.9948)$ & $(0.3572)$ & $(0.5742)$ \\
\hline \multirow[t]{3}{*}{3} & Japan & $\beta$ & -0.384 & -0.045 & -0.297 & 0.131 \\
\hline & & LRT & $3.841^{* *}$ & 0.021 & 2.168 & 0.170 \\
\hline & & P-Value & $(0.0500)$ & $(0.8843)$ & $(0.1409)$ & $(0.6803)$ \\
\hline \multirow[t]{3}{*}{2} & Germany & $\beta$ & -0.231 & -0.230 & -0.286 & 0.000 \\
\hline & & LRT & 1.271 & 0.710 & 1.992 & 0.000 \\
\hline & & P-Value & $(0.2595)$ & $(0.3993)$ & $(0.1582)$ & $(0.9998)$ \\
\hline \multirow[t]{3}{*}{1} & Switzerland & $\beta$ & -0.005 & -0.177 & 0.105 & 0.667 \\
\hline & & LRT & 0.000 & 0.389 & 0.230 & $3.469^{*}$ \\
\hline & & P-Value & $(0.9839)$ & $(0.5326)$ & $(0.6314)$ & $(0.0625)$ \\
\hline
\end{tabular}

1. The Log-Logistic function is $h_{i}=1 / 1+e^{-(\alpha+\beta \operatorname{Ln} i)}$

2. The disclosure index is obtained from the study done by Saudagaran and Biddle (1992) where the highest number represents the highest disclosure level.

3. The critical value of $\chi^{2}$ with 1 degree of freedom at $5 \%$ and $10 \%$ significance level are 3.8415 and 2.7055 respectively.

4. * Indicates significance at 5 percent level.

5. ** Indicates significance at 10 percent level. 